\title{
Kualitas buah mangga selama penyimpanan pada keranjang anyaman bambu dengan identifikasi ruang warna $L^{*}, a^{*}$ dan $b^{*}$
}

\section{Quality of mango fruit during storage on bamboo wicker basket using $L^{*}, a^{*}$, and $b^{*}$ color space identification}

Diterima : 9 Juni 2018/Disetujui : 4 Agustus 2018 / Dipublikasikan : 7 Agustus 2018

CDepartment of Crop Science, Padjadjaran University

\begin{abstract}
Postharvest handling of horticultural product is important. Proper packaging ensures the horticultural product such as mangoes cv.arumanis to maintain the quality during the distribution. One of common mango packings is the use of bamboo wicker basket pack. The purpose of this research was to investigate the change of qualitative value of mango cv.arumanis skin color during storage using bamboo wicker basket pack. This research was conducted from March to May 2018 at Horticulture Laboratory of Faculty of Agriculture, Padjadjaran University, Jatinangor. The experimental design used in this study was Completely Randomized Design (CRD) with 3 treatments and 9 replications. The treatments consisted of 0 day $\left(S_{0}\right), 7$ days $\left(S_{7}\right)$ and 14 days $\left(S_{14}\right)$ storage duration. The results revealed that the storage duration affected various parameters of skin color values of mango cv.arumanis fruit including $\mathrm{L}^{*}, \mathrm{a}^{*}$ and $\mathrm{b}^{*}$ values.
\end{abstract}

Keywords: Bamboo wicker basket - Climacteric . Fruit skin color $\cdot$ Storage

Sari Penanganan pascapanen pada produk hortikultura sangat penting. Pengemasan yang tepat akan membantu produk hortikultura seperti buah mangga arumanis dapat mempertahankan kualitasnya selama proses distribusi. Salah satu jenis pengemasan buah mangga yang umum digunakan adalah dengan mengunakan keranjang anyaman bambu. Tujuan dari penelitian ini adalah untuk mengetahui perubahan

\footnotetext{
Dikomunikasikan oleh Jajang Sauman Hamdani

Kusumiyati $^{1} \cdot$ Farida $^{1} \cdot$ W. Sutari ${ }^{1} \cdot$ S. Mubarok ${ }^{1}$

1)Staf Pengajar Program Studi Agroteknologi Fakultas

Pertanian Universitas Padjadjaran

Jl. Raya Bandung-Sumedang KM. 21 Jatinangor 40600 Tlp. 022-7796320/Fax. 022-7796316

Korespondensi: kusumiyati@unpad.ac.id
}

nilai kualitatif warna kulit buah mangga arumanis selama masa penyimpanan dalam kemasan keranjang anyaman bambu. Penelitian ini dilakukan pada Maret sampai Mei 2018 bertempat di Laboratorium Hortikultura Fakultas Pertanian, Universitas Padjadjaran, Jatinangor. Rancangan percobaan yang digunakan adalah Rancangan Acak Lengkap (RAL) dengan 3 perlakuan dan 9 ulangan. Perlakuan terdari dari 0 hari $\left(S_{0}\right), 7$ hari $\left(S_{7}\right)$ dan 14 hari $\left(S_{14}\right)$ masa simpan. Hasil penelitian menunjukkan bahwa lama masa simpan berpengaruh terhadap berbagai parameter nilai warna kulit buah mangga arumanis yang meliputi nilai $L^{*}, a^{*}$ dan $b^{*}$.

Kata kunci: Klimakterik · Keranjang anyaman bambu $\cdot$ Penyimpanan - Warna kulit buah

\section{Pendahuluan}

Jawa barat merupakan salah satu sentra produksi buah mangga arumanis. Provinsi ini menjadi penghasil buah mangga arumanis terbesar kedua di Indonesia (Anugrah, 2009). Buah mangga arumanis dijadikan salah satu komoditas unggulan yang banyak dibudidayakan di daerah Majalengka dan Sumedang. Iklim dan tanah yang cocok serta keuntungan yang tinggi dijadikan alasan banyak petani di kedua daerah tersebut menanami lahannya dengan pohon mangga.

Konsumen memilih buah berdasarkan penampilan warna kulit buah secara kasat mata. Selama masa simpan kulit buah akan mengalami perubahan warna. Buah mangga yang telah matang dan layak untuk dikonsumsi diindikasikan dengan warna kulit buah agak kekuningan. Buah muda akan menjadi busuk 
apabila terlalu lama dsimpan. Kualitas internal atau eksternal pada buah akan mengalami penurunan selama dalam proses masa simpan (Kusumiyati dkk, 2017). Buah mangga arumanis memiliki kekhasan yaitu rasanya manis namun sedikit masam dan aromanya yang harum. Karakteristik buah ini bertekstur lembut, relatif tidak berserat, memiliki aroma dan rasa yang khas juga daging buah yang tebal (Suci dkk., 2015).

Buah mangga arumanis dikirimkan ke berbagai daerah lainnya, sehingga buah melalui masa simpan saat perjalanan dari satu tempat ketempat lainnya. Para pedagang mengemas buah tersebut kedalam keranjang anyaman bambu sebagai teknik pemasaran sekaligus penanganan pasca panen. Pengemasan dengan menggunakan keranjang bambu memberikan nilai terbaik apabila dibandingkan dengan pengemas karton dan peti kayu (Amanto, 2004).

Penyimpanan buah mangga berhubungan dengan daya tahan kualitas buah. Hal tersebut mengakibatkan pedagang ataupun konsumen perlu memperhatikan masa simpan optimumnya. Buah mangga telah diuji pada penyimpanan selama 7 dan 14 hari (Basuki dkk., 2015).

Penilaian secara visual dinilai kurang akurat. Pengukuran secara kuantitatif dapat dilakukan dengan menggunakan alat chromameter. Alat ini dapat membantu melakukan penilaian terhadap warna kulit buah secara tepat dan teliti dengan menampilkan nilai $\mathrm{L}^{*}, \mathrm{a}^{*}$ dan $b^{*}$. Chromameter pernah digunakan dalam menguji warna kulit pada buah manggis dan apel (Ahmad dkk., 2014 dan Kweon et al., 2013). Berdasarkan uraian diatas, perlu diketahui perubahan nilai kualitatif warna kulit buah mangga arumanis selama masa penyimpanan dalam kemasan keranjang anyaman bambu.

\section{Bahan dan Metode}

Waktu dan Tempat. Pelaksanaan penelitian dimulai pada Maret hingga Mei 2018 di Laboratorium Hortikultura Fakultas Pertanian, Universitas Padjadjaran, Jatinangor.

Bahan dan Alat Penelitian. Buah mangga yang digunakan berasal dari Kec. Tomo Kab. Sumedang, Jawa Barat. Sampel merupakan buah yang dipanen dalam level kematangan yang seragam dan dipanen pada hari yang sama. Alat yang digunakan selama penelitian adalah keranjang anyaman bambu dan chromameter.
Pengukuran nilai warna kulit buah mangga arumanis. Warna kulit buah mangga arumanis diukur dengan menggunakan alat chromameter (Gambar 1). Alat ini dapat mengukur warna secara kuantitatif. Detektor chromameter menembakkan sinar yang nantinya akan membaca nilai warna kulit buah yang diperlukan.

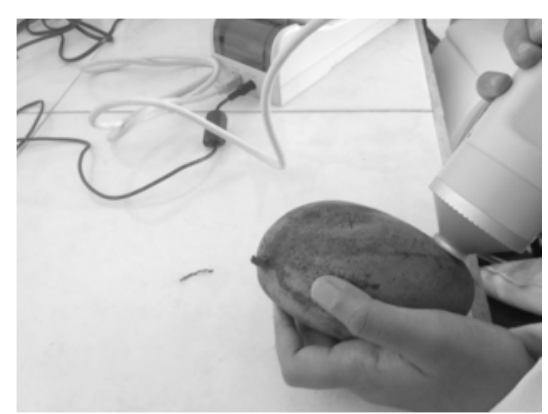

Gambar 1. Pengukuran warna kulit buah mangga menggunakan alat chromameter.

Pengukuran didapatkan dari masingmasing 3 titik. Bagian-bagian tersebut adalah atas (dekat tangkai), tengah dan bawah pada 2 sisi buah yang berbeda.Total terdapat 6 titik pengumpulan data warna (Gambar 2), data per sampel selanjutnya dirata-ratakan.

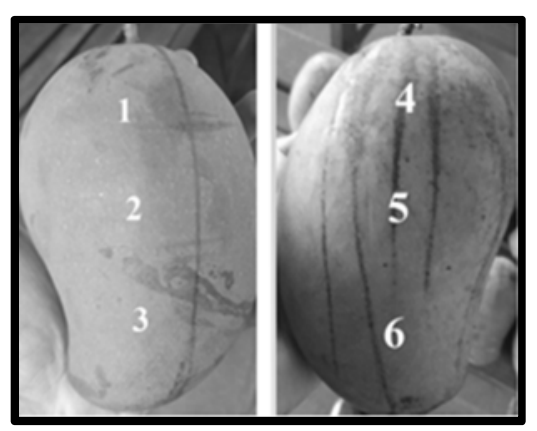

Gambar 2. Visualisasi titik pengumpulan data warna 2 sisi berbeda pada kulit buah mangga.

Nilai yang ditampilkan dari alat tersebut berupa $L^{*}$, a* dan b* (Gambar 3). Nilai $\mathrm{L}^{*}$ akan menunjukkan kecerahan dari sampel, $a^{*}$ mengindikasikan warna sampel akan mengarah dari hijau-merah sedangkan $b^{*}$ menandakan kulit buah berwarna biru menuju kuning. Pengukuran nilai warna secara kuantitatif pada nilai kecerahan ( $\mathrm{L}^{*} /$ ligthness) dari 0 (hitam) hingga 100 (putih), nilai a* yang berada pada kisaran nilai negatif berwarna hijau sedangkan nilai positif menuju pada merah dan nilai $b^{*}$ yang berada pada kisaran nilai negatif (biru) hingga positif (kuning) (Mendoza et al, 2007) 


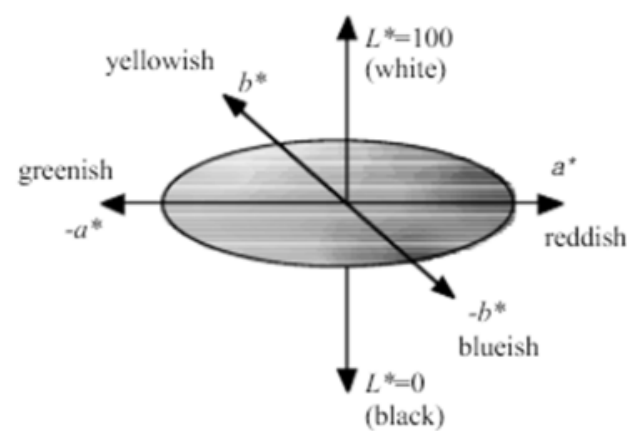

Gambar 3. Ruang warna $L^{*}, a^{*}$, dan $b^{*}$ (Ohno, 2000).

Deteksi terhadap nilai warna kulit buah menggunakan Rancangan Acak Lengkap (RAL) dengan 3 perlakuan masa penyimpanan dan 9 ulangan, sehingga didapatkan total 27 kombinasi perlakuan. Penyimpanan yang dilakukan ialah masa simpan 0 hari $\left(S_{0}\right), 7$ hari $\left(S_{7}\right)$ dan 14 hari $\left(S_{14}\right)$.

Terdapat 5 sampel tiap perlakuan per ulangan sehingga total didapatkan 135 sampel buah mangga arumanis yang diuji. Semua sampel buah dimasukkan dalam keranjang anyaman bambu (Gambar 4) dan disimpan pada suhu ruangan $\left( \pm 25^{\circ} \mathrm{C}\right)$. Data dianalisa dengan bantuan software SPSS 21, selanjutnya diuji Duncan pada taraf $5 \%$.

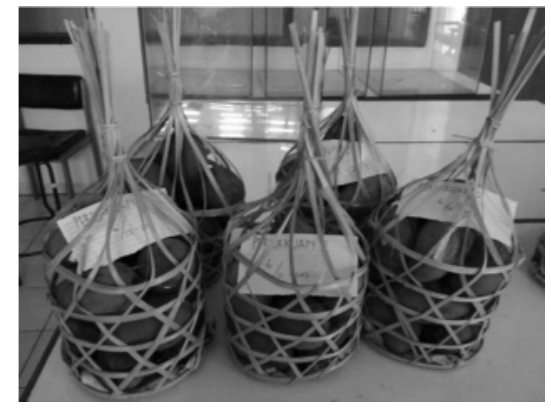

Gambar 4. Keranjang anyaman bambu yang telah diisi oleh sampel buah mangga.

\section{Hasil dan Pembahasan}

Nilai rerata $L^{*}$ pada penyimpanan buah mangga selama 0 hari berbeda nyata dengan penyimpanan selama 7 dan 14 hari (Tabel 1), sedangkan pada penyimpanan 7 dan 14 hari tidak berbeda nyata. Hal ini berarti tingkat kecerahan pada penyimpanan 0 lebih rendah karena pada saat tersebut buah mangga masih belum menunjukkan tingkat kecerahan seperti pada penyimpanan 7 buah mangga telah berubah menjadi lebih cerah, walaupun penyimpanan 7 tidak berbeda nyata secara statistika dengan penyimpanan 14 hari akan tetapi secara angka menunjukkan penurunan.

Penyimpanan dengan menggunakan keranjang anyaman bambu menyebabkan buah yang berada dibawah tertumpuk oleh buah diatasnya, sehingga seiring lamanya penyimpanan buah menjadi memar dan berpengaruh pada kecerahan warna. Tingkat kecerahan warna akan mengalami penurunan yang akan berbanding lurus dengan semakin lamanya masa simpan, buah akan mengarah pada pembusukan pada akhirnya (Ahmad dkk., 2014).

Tabel 1. Pengaruh lama penyimpanan terhadap nilai rerata $L^{*}$ buah mangga.

\begin{tabular}{lc}
\hline Perlakuan & $\mathbf{L}^{*}$ \\
\hline Masa simpan 0 hari & $48.52 \mathrm{a}$ \\
Masa simpan 7 hari & $50.39 \mathrm{~b}$ \\
Masa simpan 14 hari & $49.74 \mathrm{~b}$ \\
\hline
\end{tabular}

Keterangan : Nilai yang diberi tanda dengan huruf yang sama pada kolom yang sama menjelaskan bahwa nilai yang dimaksud tidak berbeda nyata menurut uji jarak berganda Duncan pada taraf 5\%.

Hasil pengukuran nilai rerata a* pada Tabel 2 menunjukkan nilai yang berbeda nyata pada masing-masing perlakuan. Pada ketiga perlakukan yang diujikan, buah mangga masih cenderung berwarna hijau ditunjukkan dengan nilai ketiganya dibawah 0 namun semakin lama penyimpanan warna buah bergerak menuju ke warna merah. Buah mangga tetap bisa melakukan respirasi secara mandiri meskipun sudah terlepas dari pohon dan tangkainya. Aktifitas respirasi mengakibatkan perubahan fisik dan kimia pada buah mangga, salah satunya yaitu perubahan warna buah.

Tabel 2. Pengaruh lama penyimpanan terhadap nilai rerata $a^{*}$ buah mangga.

\begin{tabular}{ll}
\hline Perlakuan & $\mathrm{a}^{*}$ \\
\hline Masa simpan 0 hari & $-10.19 \mathrm{a}$ \\
Masa simpan 7 hari & $-8.00 \mathrm{~b}$ \\
Masa simpan 14 hari & $-3.95 \mathrm{c}$ \\
\hline
\end{tabular}

Keterangan : Nilai yang diberi tanda dengan huruf yang sama pada kolom yang sama menjelaskan bahwa nilai yang dimaksud tidak berbeda nyata menurut uji jarak berganda Duncan pada taraf 5\%.

Pendugaan kematangan buah mangga secara visual umumnya dilakukan dengan cara melihat seberapa jelas warna kuning yang 
muncul pada kulit buah mangga. Tabel 3 menunjukkan nilai rerata $b^{*}$ berbeda nyata pada tiap perlakuan. Hasil pengukuran memperlihatkan bahwa makin lama penyimpanan, warna kuning pada buah mangga semakin jelas ditandai dengan semakin tingginya nilai rerata $b^{*}$. Tingginya nilai $b^{*}$ pada buah mangga dapat diindikasikan semakin tinggi pula tingkat kematangan buah tersebut.

Tabel 3. Pengaruh lama penyimpanan terhadap nilai rerata $b^{*}$ buah mangga.

\begin{tabular}{ll}
\hline Perlakuan & $\mathrm{b}^{*}$ \\
\hline Masa simpan 0 hari & $16.33 \mathrm{a}$ \\
Masa simpan 7 hari & $18.05 \mathrm{~b}$ \\
Masa simpan 14 hari & $20.88 \mathrm{c}$ \\
\hline
\end{tabular}

Keterangan : Nilai yang diberi tanda dengan huruf yang sama pada kolom yang sama menjelaskan bahwa nilai yang dimaksud tidak berbeda nyata menurut uji jarak berganda Duncan pada taraf 5\%.

Perubahan warna buah mangga selama penyimpanan. Buah mangga tergolong dalam buah yang dikategorikan klimakterik. Perubahan warna merupakan indikator yang paling mudah untuk menentukan tingkat kematangan buah mangga, perubahan tersebut diawali dari tangkai atas buah hingga kebagian bawah buah. Kulit buah mangga muda mengandung klorofil yang tinggi sehingga pigmen warna hijau lebih mendominasi dibandingkan pigmen warna lain.

Pada proses pematangan terjadi pemecahan klorofil sehingga pigmen warna lain seperti kuning dan merah muncul yang mengakibatkan warna hijau mulai terdegradasi. Tingkat kandungan klorofil pada buah yang masih hijau mengalami penurunan selama masa penyimpanan (El-Zeftawi dkk., 1988).

Penggunaan keranjang anyaman bambu selama penyimpanan. Pengemasan buah mangga dengan menggunakan keranjang anyaman bambu dilakukan dengan cara menumpuk buah secara vertikal didalam keranjang tersebut. Hal tersebut mengakibatkan buah yang berada pada sisi paling bawah tertindih oleh buah-buah yang berada diatasnya, sehingga buah tersebut mengalami kerusakan secara fisik seperti memar. Bahkan pada beberapa sampel, kulit luarnya menghitam pada sisi bagian yang tertindih oleh buah lainnya.

Kerusakan fisik berupa memar menyebabkan proses pematangan dan perubahan warna berlangsung lebih cepat dari yang seharusnya. Memar merupakan respon dari kulit dan daging buah mangga terhadap tekanan atau tumpukan yang didapatkan dari buah lainnya selama didalam keranjang anyaman bambu. Warna memar pada umumnya ditandai dengan perubahan warna kulit buah menjadi coklat kehitaman. Pergeseran warna kulit buah untuk buah yang dimasukkan kedalam kemasan akan dipengaruhi oleh berbagai faktor, diantaranya yaitu perputaran udara yang terjadi disekitar buah, suhu dan kelembaban (Amanto, 2004). Pada situasi ini, daging buah mengalami perubahan bentuk menyesuaikan dengan beban tekanan yang diterimanya. Penurunan kualitas buah secara fisik lebih cepat terjadi pada penyimpanan suhu ruang daripada penyimpanan pada suhu yang rendah (Rochayat dan Munika, 2015).

Perubahan bentuk terjadi pada dinding sel daging buah mangga yang mengalami penyempitan. Akibatnya air yang berada didalam daging buah tersebut keluar. Pada kondisi tertentu dinding sel yang menyempit mengalami kerusakan yang diakibatkan ketidakmampuannya menahan air yang terdorong keluar dari dalam sel daging buah, hal ini menyebabkan jaringan buah menjadi memar (Waluyo, 1990).

\section{Kesimpulan}

Penggunaan keranjang anyaman bambu selama penyimpanan buah mangga pada 0,7 dan 14 hari menunjukkan perubahan nilai kualitatif warna pada tiap parameter. Nilai $a^{*}$ dan $b^{*}$ tertinggi terdapat pada penyimpanan selama 14 hari. Sedangkan nilai $L^{*}$ pada penyimpanan 7 dan 14 hari tidak berbeda signifikan.

\section{Ucapan Terima Kasih}

Penulis mengucapkan terimakasih kepada semua pihak yang telah membantu selama proses penelitian ini berlangsung.

\section{Daftar Pustaka}

Ahmad, U., E. Darmawati dan N. R. Refilia. 2014. Kajian metode pelilinan terhadap umur simpan buah manggis (Garcinia mangostana) semi-cutting dalam penyim- 
panan dingin. J. Ilmu Pertanian Indonesia. 19(2): 104-110.

Amanto, B. S. 2004. Pengaruh kemasan dan susunan terhadap sifat fisik buah mangga golek selama transportasi. J. Caraka Tani. 19(1): 1-6.

Anugrah, I. S. 2009. Mendudukkan komoditas mangga sebagai unggulan daerah dalam suatu kebijakan sistem agribisnis: upaya menyatukan dukungan kelembagaan bagi eksistensi petani. J. Analisis Kebijakan Pertanian. 7(2): 189-211.

Basuki, E dan A. Prarudiyanto. 2015. Penyimpanan mangga secara modifikasi atmosfir dengan penggunakan $\mathrm{Ca}(\mathrm{OH})^{2}$ sebagai Absorbent. J. Ilmu dan Teknologi Pangan. 1(1): 8-14.

El-Zeftawi, B. M., L. Brohier, L. Dooley, F. H. Goubran, R. Holmes and B. Scott. 1988. Some maturity indices for tamarillo and pepino fruits. J. Horticultural Science. 63: 163-169.

Kusumiyati, Farida, W. Sutari dan S. Mubarok. 2017. Mutu buah sawo selama periode simpan berbeda. J. Kultivasi. 16(3): 451-455.

Kweon, H. J., I. K. Kang., M. J. Kima., J. Lee., Y. S. Moond., C. Choib., D. G. Choie and C. B. Watkinsc. 2013. Fruit maturity, controlled atmosphere delays and storage temperature affect fruit quality and incidence of storage disorders of 'fuji' apples. J. Scientia Horticulturae. 157: 6064.

Mendoza, F., P. Dejmek And J. M. Aguilera. 2007. Colour and texture analysis in classification of commercial potato chips. J. Food Research International 40(9): 11461154.

Ohno, Y. 2000. CIE fundamental for color measurements. nip \& digital fabrication conference. Society for Imaging Science and Technology: 540-545

Rochayat, Y dan V. R. Munika. 2015. Respon kualitas dan ketahanan simpan cabai merah (capsicum annuum 1.) dengan penggunaan jenis bahan pengemas dan tingkat kematangan buah. J. Kultivasi. 14(1): 65-71.

Suci, Y. T., I .W. Budiastra dan Y. A. Purwanto. 2015. Penggolongan mangga cv arumanis berdasarkan mutu internal selama penyimpanan dingin dengan near infrared reflectance spectroscopy (nirs). J. Keteknikan Pertanian. 3(2): 121-128.

Waluyo, S. B. 1990. Pengkajian dampak getaran mekanik pengangkutan truk terhadap jeruk dalam kemasan. Tesis. Fakultas Pascasarjana, Institut Pertanian Bogor 